\title{
Influence of altitude on phenology of selected plant species in the Alpine region (1971-2000)
}

\author{
Chiara Ziello*, Nicole Estrella, Mariya Kostova, Elisabeth Koch, Annette Menzel \\ Chair of Ecoclimatology, Technische Universität München, Am Hochanger 13, 85354 Fresing, Germany \\ Department of Climatology, Zentralanstalt für Meteorologie und Geodynamik, Hohe Warte 38, 1190 Wien, Austria
}

\begin{abstract}
We present a quantitative and qualitative analysis of the influence of altitude on plant phenology over an area, delimited by 46 to $49^{\circ} \mathrm{N}$ latitude and 5 to $15^{\circ} \mathrm{E}$ longitude, that includes major parts of the Alpine region for the period 1971-2000. Our attention is focused on flowering of widely distributed plants in Europe, including some important allergenic species. We calculated the dependence of phenological mean dates on altitude for different phenophases as a linear regression. Results show a statistically significant linear dependence $(p<0.0001)$ for each phenophase, with regression coefficients that range from $0.92 \pm 0.21 \mathrm{~d}(100 \mathrm{~m})^{-1}$ altitude for beginning of flowering of Norway spruce to $4.56 \pm 0.21 \mathrm{~d}(100 \mathrm{~m})^{-1}$ for beginning of flowering of common hazel. Phenological temporal trends and thermal temporal trends show a less strong dependence on altitude, predominantly non-significant. The most significant regression coefficients are negative for phenological trends (beginning of flowering of common alder, $-0.065 \pm 0.028 \mathrm{~d} \mathrm{yr}^{-1}(100 \mathrm{~m})^{-1}, \mathrm{p}=0.0187$, and Norway spruce, $\left., 0.049 \pm 0.020 \mathrm{~d} \mathrm{yr}^{-1}(100 \mathrm{~m})^{-1}, \mathrm{p}=0.0167\right)$ and positive for temperature trends (February, $\left.0.0017^{\circ} \mathrm{C} \mathrm{yr}^{-1}(100 \mathrm{~m})^{-1}, \mathrm{p}<0.0001\right)$. The significant linear dependence of February temperature trends on altitude induces an inverse significant linear dependence for phenological trends of flowering of common alder (occurring in March). The prevalence of negative mean phenological trends suggests a stronger advance of flowering phases at higher altitude. Finally, a regional analysis suggests a tendency towards a stronger altitudinal response in the northern than in the southern Alps.
\end{abstract}

KEY WORDS: Phenology $\cdot$ Alpine region $\cdot$ Altitude $\cdot$ Altitudinal gradients $\cdot$ Onset dates $\cdot$ Temporal trends $\cdot$ Allergenic plants

\section{INTRODUCTION}

In the past, mountain regions were regarded as a healthy shelter for hay fever sufferers due to the low presence of airborne pollen, compared to plain regions (Michel et al. 1976). Recently, however, highlands seem to be more strongly affected by climate change than other regions (Cannone et al. 2008). Global warming could be a major cause of biodiversity change on mountain tops. A general rearrangement of the Alpine flora could result from an elevational shift in species ranges, following possible vulnerability of the resident species to invasion from newcomers (Walther et al. 2002). Phenology, the science of recurrent seasonal natural events, can help scientists understand changes in plants of the Alpine region that are due to the influence of global warming, and phenological observations have gained an important role in assessing the impacts of climate change (Menzel 2002).

Altitude drives phytophenological phases mainly by means of a temperature decrease of about $0.6^{\circ} \mathrm{C}$ every $100 \mathrm{~m}$ (Barry 1981). Although temperature can be considered the most important forcing factor in plant physiology (Defila \& Clot 2005), other effects concomitant with an altitude increase are: (1) progressive reduction of land area; (2) decrease of total atmospheric pressure and partial pressure of all the component gases (concentrations of $\mathrm{O}_{2}$ and $\mathrm{CO}_{2}$ are crucial for vegetation 
and are of vital importance for animal life); and (3) increment of solar radiation during clear sky conditions, with a higher percentage of the UV-B component (Körner 2007).

Several studies have been carried out to investigate the effects of altitude on phenological phases and their temporal trends in different zones of the Alpine region (Dittmar \& Elling 2006, Larcher 2006). However, discrepancies in the results due to the different zones taken into account still need to be clarified (Defila \& Clot 2001, Studer et al. 2005). Our main objective is therefore to gain a better comprehension of how phenophases and trends of allergenic plants depend on altitude. We studied an extended fraction of the Alpine area with the aim of unambiguously pointing out (if present) such a dependence. Finally, to complete this geographical overview, we offer a brief analysis of the influence of land zones as a further forcing factor to identify other possible dependences.

\section{MATERIALS AND METHODS}

In the present study we used the dataset collected within the European Cooperation in Science and Technology (COST) action 725 'Establishing a European phenological data platform for climatological applications' (www.cost725.org). Among this extensive dataset, comprising more than 125000 digitally available

Table 1. Phenological phases and plant species considered in the present study

\begin{tabular}{|ll|}
\hline Phase & Species (common name) \\
\hline Full flowering FF & $\begin{array}{l}\text { Aesculus hippocastanum L. } \\
\text { (horse chestnut) }\end{array}$ \\
Beginning of flowering BF & $\begin{array}{l}\text { Alnus glutinosa L. } \\
\text { (common alder) } \\
\text { Corylus avellana L. } \\
\text { (common hazel) }\end{array}$ \\
Beginning of flowering BF & $\begin{array}{l}\text { Dactylis glomerata L. } \\
\text { (cocksfoot grass) }\end{array}$ \\
Beginning of flowering BF & $\begin{array}{l}\text { Picea abies (L.) H. Karst. } \\
\text { (Norway spruce) }\end{array}$ \\
First flowers open FFO & $\begin{array}{l}\text { Salix caprea L. } \\
\text { (goat willow) }\end{array}$ \\
Full flowering FF & $\begin{array}{l}\text { Sambucus nigra L. } \\
\text { (black elder) } \\
\text { Secale cereale M. Bieb. } \\
\text { (rye) }\end{array}$ \\
First flowers open FFO & $\begin{array}{l}\text { Tilia cordata Mill. } \\
\text { (small-leaved lime) }\end{array}$ \\
Full flowering FF & $\begin{array}{l}\text { Vitis vinifera L. } \\
\text { (common grape vine) }\end{array}$ \\
\hline &
\end{tabular}

observational series of various phases in 542 plant and 19 animal species from 21 European countries for 1971-2000 (Menzel et al. 2006, Rosenzweig et al. 2007), we selected widely distributed plants, including some important allergenic trees (e.g. Corylus avellana L. and Alnus glutinosa L.) and grasses (e.g. Dactylis glomerata L. and Secale cereale M.Bieb.) (Table 1). Monitoring of allergenic plants is of great importance in relation to climate change: modifications in range distribution and flowering (i.e. pollination) time for these species are important possible consequences of global warming. They affect the life quality of pollen-induced allergies sufferers, representing 10 to $20 \%$ of the total population of Europe (WHO 2003). All phenological phases (see Table 1 for abbreviations) taken into account are related to different secondary stages of flowering, according to the extended BBCH-scale (Biologische Bundesanstalt, Bundessortenamt and Chemical industry). The variety of the considered phenophases is due to the multiple data provenances within the COST dataset, to which information converges from various phenological networks and hence from different monitoring schemes. We also used the E-Obs dataset from the EUFP6 project ENSEMBLES for monthly mean temperature data in Europe (Haylock et al. 2008).

The study area $\left(45^{\circ} 50^{\prime}\right.$ to $49^{\circ} \mathrm{N}, 5$ to $\left.15^{\circ} \mathrm{E}\right)$ includes a good part of the Alps and their surroundings in Austria, Germany and Switzerland. In this territory are located 1399 phenological stations: 948 in Germany, 277 in Austria, 152 in Switzerland and 22 International Phenological Gardens (IPGs), with altitude between 100 and $1900 \mathrm{~m}$ above sea level (a.s.l.). Geographical position and relative altitude of each station are shown in Fig. 1. Temperature data were provided in a regular grid of resolution $\left(0.5^{\circ}\right.$ latitude $\times 0.5^{\circ}$ longitude) for a similar area, between 46 and $49^{\circ} \mathrm{N}$ and 5 and $15^{\circ} \mathrm{E}$.

To calculate the average phenological onset dates, we decided to select only time series with $>15$ yr of observations for the years 1971-2000. This threshold was considered high enough to make mean dates a better statistical estimate and low enough not to reject too many time series.

Temporal trends of phenodates (one for each station and each phenophase) were obtained as coefficients of linear regressions of phenological date (day of the year) versus year over the period 1971-2000. A negative value of a trend hence indicates an earlier occurrence of the respective phase, whereas a positive value represents a delay. On the other hand, temporal trends in monthly or seasonal mean temperature were calculated for every grid cell and plotted against years for the same period (1971-2000). In this case, if the coefficient of the linear regression is positive it is related to an increase in temperature, if it is negative to a decrease. 


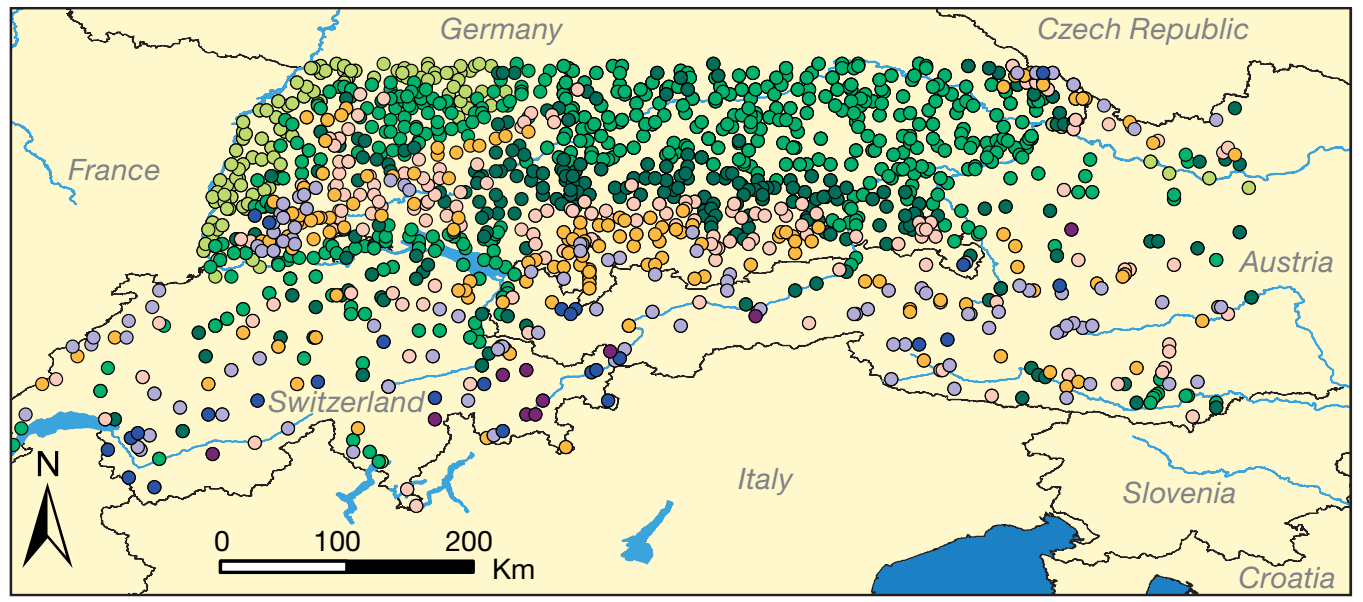

\begin{tabular}{|cc|}
$\begin{array}{c}\text { Phenological stations } \\
\text { Altitude classes } \\
\text { (m a.s.I.) }\end{array}$ \\
\hline & $110-300$ \\
0 & $300-500$ \\
0 & $500-600$ \\
0 & $600-700$ \\
0 & $700-850$ \\
0 & $850-1200$ \\
\hline & $1200-1500$ \\
0 & $1500-1900$ \\
\hline
\end{tabular}

Fig. 1. Geographical positions and altitudes of phenological stations. Balancing station numbers per class without losing altitudinal representativeness resulted in unequal altitudinal ranges

To better understand changes in behaviour of altitudinal gradients of both mean onset dates and phenological temporal trends that could depend on regional differences, we selected 7 different smaller areas inside that Alpine region previously indicated as the reference area of COST dataset (Fig. 2). Germany was divided into the Black Forest, Schwarzwald region (SW) and the region south of the Danube and prealpine plateau (SDPP); Austria into the northern prealpine (NPR), alpine (AR) and southern prealpine regions (SPR); and Switzerland into the central (CR) and alpine regions (AR). GIS software was used to select the zones in which the calculation of altitudinal gradients was possible, discarding phenostations without corresponding sites at different altitudes.

\section{RESULTS AND DISCUSSION}

Phenological mean dates were considered as a function of altitude of the station. Group representations in Fig. 3 show these altitudinal gradients (each series describes the behaviour of a different phenophase, and each point of a series represents a mean date of a single phenostation). A linear regression model has been used to fit these datasets and the results are shown in Table 2 .

The very high level of significance confirms for each series the existence of a linear dependence between phenological onset dates and altitude. The value of this altitude response (Table 2) ranges from $0.92 \pm 0.21 \mathrm{~d}$ $(100 \mathrm{~m})^{-1}$ for Norway spruce BF to $4.56 \pm 0.21 \mathrm{~d}$
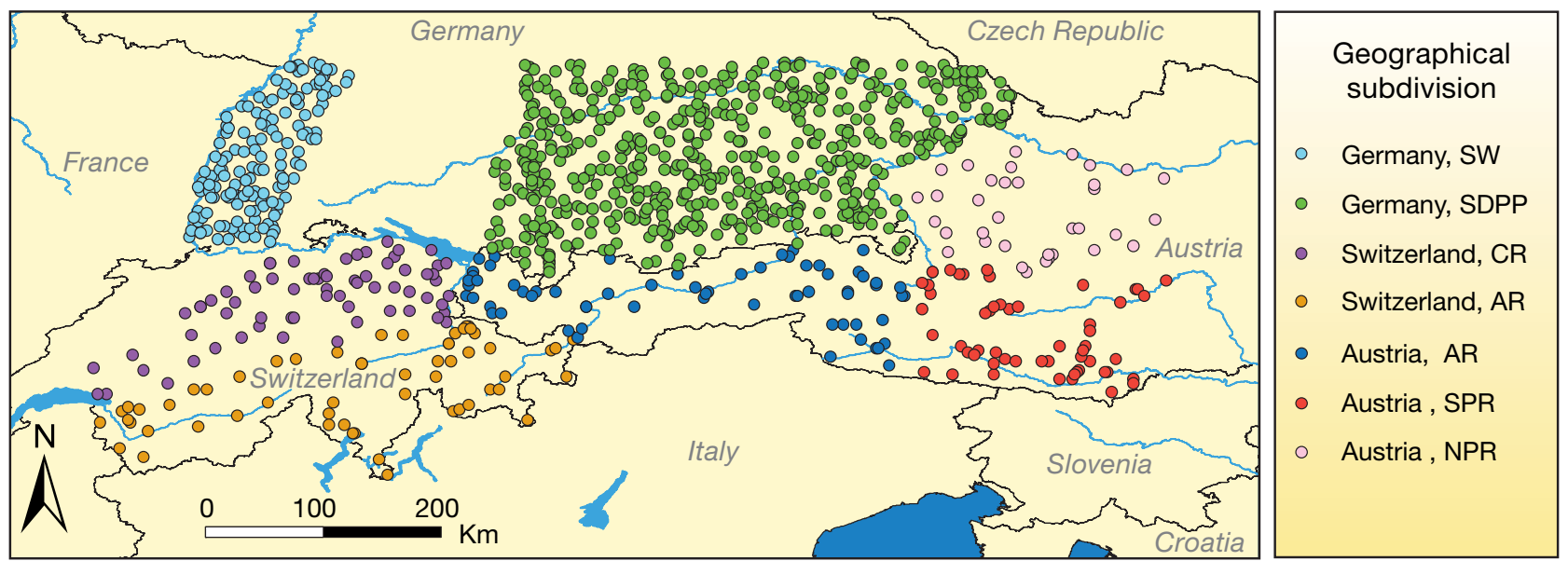

Fig. 2. Geographical subdivision of the Alpine region originally defined in Fig. 1. Seven zones were selected to calculate altitudinal gradients by using GIS software. Germany (D) was divided into the Black Forest (Schwarzwald) region (SW) and the region south of the Danube and prealpine plateau (SDPP); Austria (A) into the northern prealpine (NPR), alpine (AR) and southern prealpine regions (SPR); and Switzerland $(\mathrm{CH})$ into the central $(\mathrm{CR})$ and alpine regions $(\mathrm{AR})$ 


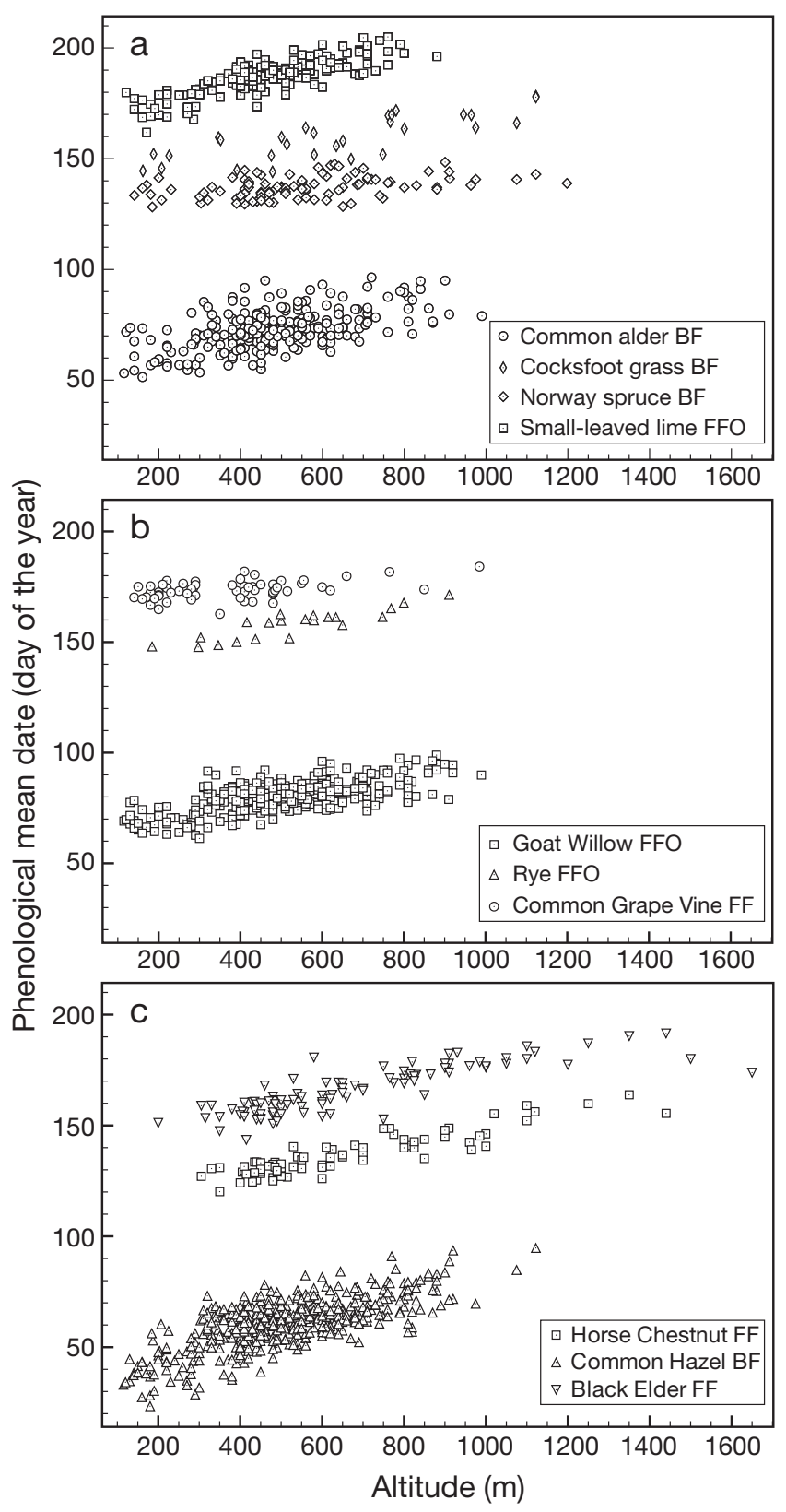

Fig. 3. Phenological mean dates versus altitude, calculated in the Alpine region delimited by $45^{\circ} 50^{\prime}$ to $49^{\circ} \mathrm{N}$ and 5 to $15^{\circ} \mathrm{E}$. Each altitudinal series is related to a different phenophase. Means are calculated over temporal series of more than $15 \mathrm{yr}$. Table 2 shows results of a linear regression model used to fit these datasets. BF: beginning of flowering; FFO: first flowers open; FF: full flowering

$(100 \mathrm{~m})^{-1}$ for common hazel BF. These differences are probably due to the different sensitivity of species to changes in temperature. The value of $R^{2}$ is $>0.50$ for 6 out of 10 phenophases, indicating that variability of dates may be well explained by altitude dependence; in the remaining cases, a lower level of relevance (never <0.17) may have been caused by a restricted altitudinal range with respect to the potential range of the species.

Considering a temperature response of -1 to $-5 \mathrm{~d}$ ${ }^{\circ} \mathrm{C}^{-1}$ for flowering phases in Europe (Menzel et al. 2006), under the influence of an altitudinal gradient of temperature of $-0.6^{\circ} \mathrm{C}(100 \mathrm{~m})^{-1}$ we should expect to observe an altitude response that ranges from 0.6 to $3.0 \mathrm{~d}(100 \mathrm{~m})^{-1}$. Altitudinal gradients of phenodates are out of this range only for common hazel BF (4.56 \pm $\left.0.21 \mathrm{~d}(100 \mathrm{~m})^{-1}\right)$ and small-leaved lime FFO (4.03 \pm $\left.0.24 \mathrm{~d}(100 \mathrm{~m})^{-1}\right)$. Both seem to be triggered by relatively early onset dates in altitudes below $400 \mathrm{~m}$ a.s.l. The 2 phases with the lowest altitudinal gradients of onset dates, Norway spruce BF and common grape vine $F F$, are related to the only evergreen species and a warm-loving agricultural species, respectively. Anyway, there is the possibility that the inhomogeneous altitudinal distribution of phenostations results in biased gradients: this could be the case of horse chestnut and common grape vine, for which most of the stations are concentrated at the lower end of the altitudinal range (see Fig. 3). In fact, regarding the calculation of the regression coefficients, this gives high weight to the less numerous elevated stations, which

Table 2. Altitudinal gradients analysis of phenological mean dates across the Alpine region, based on 15+ year means during the period 1971-2000. Gradients have been calculated as coefficients of linear regression ( \pm SE). BF: beginning of flowering; FFO: first flowers open; FF: full flowering; CH: Switzerland; D: Germany; A: Austria

\begin{tabular}{|c|c|c|c|c|c|c|}
\hline Phenological phase & Gradient (d per $100 \mathrm{~m}$ ) & $\mathrm{R}^{2}$ & $\mathrm{p}$ & No. stations & Altitudinal range (m) & Country \\
\hline Horse chestnut FF & $3.35 \pm 0.18$ & 0.82 & $<0.0001$ & 77 & $300-1450$ & $\mathrm{CH}$ \\
\hline Common alder BF & $2.92 \pm 0.28$ & 0.30 & $<0.0001$ & 254 & $100-1000$ & D \\
\hline Common hazel BF & $4.56 \pm 0.21$ & 0.52 & $<0.0001$ & 436 & $100-1100$ & A, D \\
\hline Cocksfoot grass BF & $2.80 \pm 0.41$ & 0.64 & $<0.0001$ & 29 & $150-1100$ & A \\
\hline Norway spruce BF & $0.92 \pm 0.21$ & 0.17 & $<0.0001$ & 99 & $150-1200$ & A, D \\
\hline Goat willow FFO & $2.51 \pm 0.16$ & 0.42 & $<0.0001$ & 359 & $100-1000$ & $\mathrm{D}$ \\
\hline Black elder FF & $3.12 \pm 0.21$ & 0.71 & $<0.0001$ & 94 & $200-1650$ & $\mathrm{CH}$ \\
\hline Rye FFO & $3.22 \pm 0.39$ & 0.78 & $<0.0001$ & 21 & $150-900$ & A \\
\hline Small-leaved lime FFO & $4.03 \pm 0.24$ & 0.63 & $<0.0001$ & 164 & $100-900$ & $\mathrm{D}$ \\
\hline Common grape vine FF & $1.13 \pm 0.26$ & 0.24 & $<0.0001$ & 59 & $150-1000$ & $\mathrm{CH}$ \\
\hline
\end{tabular}



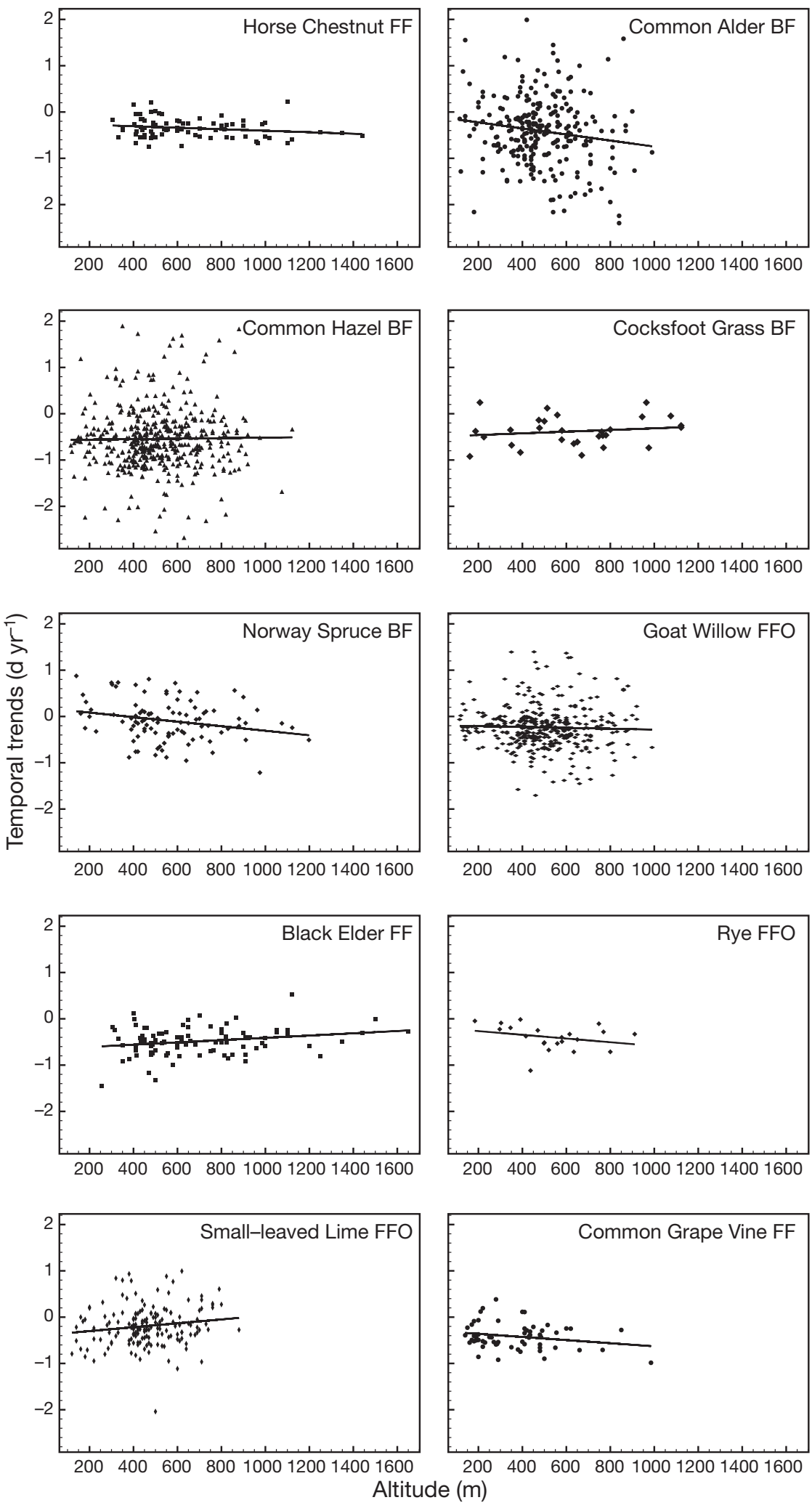

Fig. 4. Temporal trends (1971-2000) of 15+ year phenological series versus altitude, together with their linear regressions, in the Alpine region delimited by $45^{\circ} 50^{\prime}$ to $49^{\circ} \mathrm{N}$ and 5 to $15^{\circ} \mathrm{E}$. Results of linear regressions are reported in Table 3. BF: beginning of flowering; FFO: first flowers open; FF: full flowering could be scarcely representative of their altitude due to the tendency of these species to be situated in thermally favourable places.

Temporal trends of phenodates, calculated for each phenological station, are reported for each phase as a function of altitude in Fig. 4. Results of a linear regression model are summarized in Table 3.

The analysis of altitudinal gradients of phenological temporal trends leads to less clear results in comparison to those of phenological gradients. Values (Table 3) ranges from $0.042 \pm$ 0.022 (small-leaved lime FFO) to $-0.065 \pm 0.028 \mathrm{~d} \mathrm{yr}^{-1}(100 \mathrm{~m})^{-1}(\mathrm{com}-$ mon alder $\mathrm{BF}$ ); however, these are statistically significant $(p<0.05)$ only for 3 phenophases (common alder $\mathrm{BF}$, Norway spruce BF and black elder FF) and the relevance, as indicated by $\mathrm{R}^{2}$, is low for every phase. In particular, $\mathrm{R}^{2}$ never exceeds 0.075 , reached for the dataset with the minimum number of experimental points (rye FFO). Moreover, the datasets with the largest number of stations involved (common hazel BF, 436; goat willow, 359) have the smallest $R^{2}$ value (0.0002 and 0.0012 , respectively): this finding strongly suggests the lack of dependence between temporal trends and altitude.

However, negative values of altitudinal gradients of temporal trends occur more often (6 out of 10) than positive values, and among the negative coefficients are included the most significant ones (trends for common alder $B F, p=0.0187$; Norway spruce $B F, p=0.0167)$. Moreover, mean values of trends are negative for each phenophase. These findings can be explained by a major sensitivity of highland plants to temperature changes, which leads to a stronger reaction to climate change (Defila \& Clot 2005).

Temporal trends in temperature are shown in Fig. 5. Here trends in monthly mean temperatures (January to May) and spring mean temperature (calculated as the mean of the March-May period) have been plot- 
Table 3. Altitudinal gradient analysis of phenological temporal trends (19712000 ) in the Alpine region. Gradients have been calculated as coefficients of linear regression $( \pm \mathrm{SE})$. BF: beginning of flowering; FFO: first flowers open; FF: full flowering

\begin{tabular}{|c|c|c|c|c|c|}
\hline $\begin{array}{l}\text { Phenological } \\
\text { phase }\end{array}$ & $\begin{array}{c}\text { Gradient } \\
\left(\mathrm{d} \mathrm{yr}^{-1} \text { per } 100 \mathrm{~m}\right)\end{array}$ & $\mathrm{R}^{2}$ & $\mathrm{p}$ & $\begin{array}{l}\text { No. } \\
\text { stations }\end{array}$ & $\begin{array}{l}\text { Mean trend } \\
\left( \pm \text { SE, d yr }{ }^{-1}\right)\end{array}$ \\
\hline Horse chestnut FF & $-0.0162 \pm 0.0095$ & 0.037 & 0.0943 & 77 & $-0.348 \pm 0.024$ \\
\hline Common alder BF & $-0.065 \pm 0.028$ & 0.022 & 0.0187 & 254 & $-0.410 \pm 0.046$ \\
\hline Common hazel BF & $0.006 \pm 0.018$ & 0.0002 & 0.7559 & 436 & $-0.543 \pm 0.032$ \\
\hline Cocksfoot grass BF & $0.018 \pm 0.021$ & 0.026 & 0.4066 & 29 & $-0.382 \pm 0.059$ \\
\hline Norway spruce BF & $-0.049 \pm 0.020$ & 0.058 & 0.0167 & 99 & $-0.090 \pm 0.044$ \\
\hline Goat willow FFO & $-0.009 \pm 0.014$ & 0.0012 & 0.5210 & 359 & $-0.237 \pm 0.025$ \\
\hline Black elder FF & $0.025 \pm 0.011$ & 0.053 & 0.0256 & 94 & $-0.490 \pm 0.031$ \\
\hline Rye FFO & $-0.040 \pm 0.032$ & 0.075 & 0.2290 & 21 & $-0.399 \pm 0.058$ \\
\hline $\begin{array}{l}\text { Small-leaved } \\
\text { lime FFO }\end{array}$ & $0.042 \pm 0.022$ & 0.023 & 0.0547 & 164 & $-0.189 \pm 0.033$ \\
\hline $\begin{array}{l}\text { Common grape } \\
\text { vine FF }\end{array}$ & $-0.034 \pm 0.020$ & 0.048 & 0.0970 & 59 & $-0.418 \pm 0.036$ \\
\hline
\end{tabular}

ted against altitude, with each point representing the mean temperature of a grid cell $\left(0.5^{\circ}\right.$ latitude $\times 0.5^{\circ}$ longitude $)$ with respect to the mean altitude of such a cell.

Additionally, temporal trends in temperature do not show a clear dependence on altitude (Fig. 5) except for February, when temperature trends show a significant and relevant dependence $\left(\mathrm{R}^{2}=0.30, \mathrm{p}<0.0001\right)$. Apropos of this, it is important to notice the effect of an altitudinal dependence of thermal trends in February on phenological trends of common alder $\mathrm{BF}, \mathrm{a}$ phenophase that presents one of the best significance levels of linear regres-
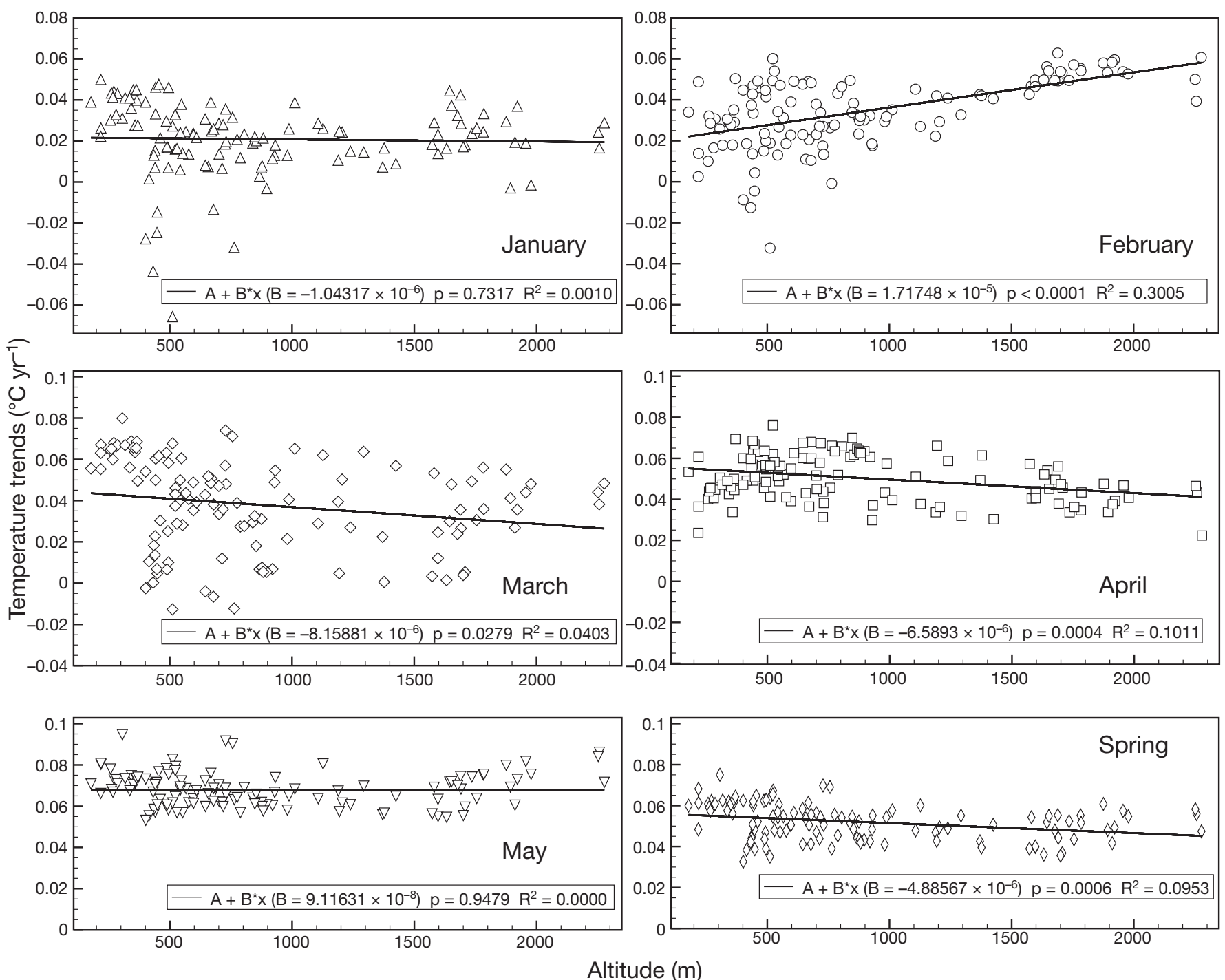

Fig. 5. Temporal trends (1971-2000) of monthly mean temperatures and spring (March-May) mean temperature versus altitude in the Alpine region. Each point represents a $0.5^{\circ}$ latitude $\times 0.5^{\circ}$ longitude cell of a grid that covers an area delimited by 46 to $49^{\circ} \mathrm{N}$ and 5 to $15^{\circ} \mathrm{E}$ 
sion ( $p=0.0187$, see Table 3$)$. This is due to the greater sensitivity of species to the temperature of the month preceding their flowering time (Larcher 2006, Menzel et al. 2006), which is in March for common alder. Hence a stronger dependence of thermal trends on altitude in February induces a more significant dependence of phenological trends on altitude for common alder $\mathrm{BF}$, occurring about $30 \mathrm{~d}$ later.

The same procedure and statistical analyses have been employed with reference to a division into zones of the Alpine region previously considered in its entirety. Table 4 reports altitudinal gradients analysis of onset dates. The decrease in observations for each phenophase following the geographical subdivision compromises the statistical quality. Plus, a comparison between the same phenophases among different zones can imply a comparison between datasets related to a different sample dimension and a different altitude

Table 4. Altitudinal gradients analysis of mean onset dates: geographical subdivision of data reported in Table 2. See Fig. 2 for a key to abbreviations for the different geographical zones. BF: beginning of flowering; FFO: first flowers open; FF: full flowering

\begin{tabular}{|c|c|c|c|c|c|}
\hline Area & $\begin{array}{c}\text { Phenological } \\
\text { phase }\end{array}$ & $\begin{array}{c}\text { Gradient } \\
\text { SE, d per } 100 \mathrm{~m} \text { ) }\end{array}$ & $R^{2}$ & $\mathrm{p}$ & $\begin{array}{l}\text { No. } \\
\text { stations }\end{array}$ \\
\hline \multicolumn{6}{|c|}{ Germany } \\
\hline \multirow[t]{6}{*}{ SW } & Common alder BF & $3.32 \pm 0.51$ & 0.57 & $<0.0001$ & 34 \\
\hline & Common hazel BF & $5.43 \pm 0.36$ & 0.81 & $<0.0001$ & 57 \\
\hline & Norway spruce BF & $0.53 \pm 0.29$ & 0.29 & 0.1067 & 10 \\
\hline & Goat willow FFO & $3.30 \pm 0.23$ & 0.80 & $<0.0001$ & 52 \\
\hline & Small-leaved lime FFO & $3.43 \pm 0.66$ & 0.62 & $<0.0001$ & 19 \\
\hline & Common grape vine FF & $1.47 \pm 0.98$ & 0.12 & 0.1530 & 19 \\
\hline \multirow[t]{5}{*}{ SDPP } & Common alder BF & $1.48 \pm 0.49$ & 0.063 & 0.0030 & 139 \\
\hline & Common hazel BF & $2.12 \pm 0.34$ & 0.15 & $<0.0001$ & 216 \\
\hline & Norway spruce BF & $2.19 \pm 0.44$ & 0.36 & $<0.0001$ & 46 \\
\hline & Goat willow FFO & $0.61 \pm 0.23$ & 0.036 & 0.0084 & 194 \\
\hline & Small-leaved lime FFO & $2.66 \pm 0.44$ & 0.29 & $<0.0001$ & 91 \\
\hline \multicolumn{6}{|l|}{ Austria } \\
\hline \multirow[t]{3}{*}{ NPR } & Common hazel BF & $5.45 \pm 0.68$ & 0.86 & $<0.0001$ & 12 \\
\hline & Cocksfoot grass BF & $3.67 \pm 0.68$ & 0.85 & 0.0030 & 7 \\
\hline & Rye FFO & $3.74 \pm 0.89$ & 0.86 & 0.0245 & 5 \\
\hline \multirow[t]{3}{*}{$\mathrm{AR}$} & Common hazel BF & $2.6 \pm 2.0$ & 0.24 & 0.2616 & 7 \\
\hline & Cocksfoot grass BF & $4.2 \pm 1.1$ & 0.75 & 0.0114 & 7 \\
\hline & Norway spruce BF & $1.33 \pm 0.80$ & 0.41 & 0.1716 & 6 \\
\hline \multirow[t]{4}{*}{ SPR } & Common hazel BF & $3.85 \pm 0.87$ & 0.64 & 0.0010 & 13 \\
\hline & Cocksfoot grass BF & $4.39 \pm 0.79$ & 0.86 & 0.0026 & 7 \\
\hline & Norway spruce BF & $1.61 \pm 0.50$ & 0.72 & 0.0326 & 6 \\
\hline & Rye FFO & $2.99 \pm 0.57$ & 0.85 & 0.0032 & 7 \\
\hline \multicolumn{6}{|c|}{ Switzerland } \\
\hline \multirow[t]{3}{*}{$\mathrm{CR}$} & Horse chestnut FF & $3.49 \pm 0.33$ & 0.75 & $<0.0001$ & 38 \\
\hline & Black elder FF & $4.11 \pm 0.42$ & 0.68 & $<0.0001$ & 46 \\
\hline & Common grape vine FF & $0.75 \pm 0.72$ & 0.11 & 0.3277 & 11 \\
\hline \multirow[t]{3}{*}{$\mathrm{AR}$} & Horse chestnut FF & $3.54 \pm 0.32$ & 0.88 & $<0.0001$ & 19 \\
\hline & Black elder FF & $2.70 \pm 0.39$ & 0.67 & $<0.0001$ & 26 \\
\hline & Common grape vine FF & $2.79 \pm 0.44$ & 0.91 & 0.0031 & 6 \\
\hline
\end{tabular}

range. Keeping in mind these considerations, it is still possible to undertake a systematic zone-by-zone analysis of altitudinal gradients of mean phenodates, by means of the most significant and relevant series.

There is agreement (see Table 4) between common hazel BF in Austria, NPR $\left(5.45 \pm 0.68 \mathrm{~d}(100 \mathrm{~m})^{-1}\right)$ and Germany, SW $\left(5.43 \pm 0.36 \mathrm{~d}(100 \mathrm{~m})^{-1}\right)$, whereas in Austria, SPR a smaller altitude response is observed $\left(3.85 \pm 0.87 \mathrm{~d}(100 \mathrm{~m})^{-1}\right)$. This is in accord with a difference in influence of altitude in Switzerland, between the southern part of the Alps (where an earlier onset of flowering phases occurs) and the northern part (Defila \& Clot 2005, Larcher 2006). As further confirmation, the same behaviour has been found for black elder FF: a smaller gradient of phenodates in Switzerland, AR $\left(2.70 \pm 0.39 \mathrm{~d}(100 \mathrm{~m})^{-1}\right)$ than in CR $(4.11 \pm$ $\left.0.42 \mathrm{~d}(100 \mathrm{~m})^{-1}\right)$. Involving only the northern part of the Alpine region, small-leaved lime FFO presents agreement between Germany, SDPP $\left(2.66 \pm 0.44 \mathrm{~d}(100 \mathrm{~m})^{-1}\right)$ and SW $\left(3.43 \pm 0.66 \mathrm{~d}(100 \mathrm{~m})^{-1}\right)$.

On the other hand, other phases present substantial agreement between northern and southern Alps. We observe such behaviour (see Table 4) for horse chestnut FF between Switzerland, AR $\left(3.54 \pm 0.32 \mathrm{~d}\left(100 \mathrm{~m}^{-1}\right)\right.$ and CR $\left(3.49 \pm 0.33 \mathrm{~d}(100 \mathrm{~m})^{-1}\right)$, as well as for Norway spruce BF between Austria, SPR $\left(1.61 \pm 0.50 \mathrm{~d}(100 \mathrm{~m})^{-1}\right)$ and Germany, SDPP $\left(2.19 \pm 0.44 \mathrm{~d}(100 \mathrm{~m})^{-1}\right)$, and cocksfoot grass BF among Austria, SPR $\left(4.39 \pm 0.79 \mathrm{~d}(100 \mathrm{~m})^{-1}\right), \mathrm{NPR}$ $\left(3.67 \pm 0.68 \mathrm{~d}(100 \mathrm{~m})^{-1}\right)$ and AR $(4.2 \pm$ $\left.1.1 \mathrm{~d}(100 \mathrm{~m})^{-1}\right)$. Also rye FFO does not show a statistically significant difference between Austria, SPR (2.99 \pm $\left.0.57 \mathrm{~d}(100 \mathrm{~m})^{-1}\right)$ and Austria, NPR $\left(3.74 \pm 0.89 \mathrm{~d}(100 \mathrm{~m})^{-1}\right)$, even if these 2 areas involve both northern and southern parts of the Alps; but in this case, a restricted number of stations together with a particularly narrow altitude range (300 to $800 \mathrm{~m}$ in the north, 150 to $650 \mathrm{~m}$ in the south) may have statistically compromised the tendency towards a stronger altitudinal response to the north of the Alpine arch.

Regarding the geographical distribution of values of phenological temporal trends, the general lack of statistical significance does not allow for any systematic differences between zones to be identified. For this reason, such data have not been reported. 


\section{CONCLUSIONS}

The temperature decrease due to the increase in geographical elevation causes a significant linear dependence on altitude of all the phenodates collected according to our selection criteria. A similar behaviour over the Alpine region, even if related to different phenophases and more restricted areas, has been reported in other studies (Studer et al. 2005, Dittmar \& Elling 2006, Larcher 2006).

The mean temporal trends of all phases underline the strong response of spring phenology to warming in recent decades. However, concerning altitudinal gradients of temporal trends, the low level of statistical significance does not permit the hypothesis of any dependence on altitude. On the contrary, it suggests that altitude does not influence phenological temporal trends, except for common alder BF and Norway spruce BF. The first of these 2 phenophases is influenced by the mean temperature of the month preceding its onset, February, the only month when temperature trends show a significant and consistently relevant linear dependence on altitude. The influence of the temperature of the preceding month on flowering phenodates has been detected in previous investigations (Larcher 2006, Menzel et al. 2006), and the present study finds that the external dependence on altitude induces a direct connection between temporal trends in temperature and in phenology.

The lack of altitudinal dependence of phenological temporal trends is partially confirmed in Studer et al. (2005), in which a linear altitudinal dependence of phenological temporal trends was found in the northern but not in the southern Alps.

Finally, a systematic zone-by-zone analysis of altitudinal gradients of phenodates suggests a stronger tendency towards an altitudinal response of some phenophases in the northern part of the Alpine region than in the south. This result is supported by Larcher (2006), in which a discrepancy of up to $0.9 \mathrm{~d}(100 \mathrm{~m})^{-1}$ among altitudinal gradients of flowering onset dates of lilac (Syringa vulgaris L.) between the northern and southern Alps was detected, and is also compatible with the general tendency towards an advance in flowering dates being more pronounced in the southern than the northern Alps (Defila \& Clot 2005).

Acknowledgements. We acknowledge the E-Obs dataset from the EU-FP6 project ENSEMBLES (www.ensembles-eu. org) and the data providers in the ECA\&D project (http://eca. knmi.nl). We are also grateful to all the anonymous reviewers who contributed, with precise and interesting suggestions as well as pertinent questions, to appreciably improve this paper. Phenological data have been provided by COST action 725 (www.cost725.org). This study was supported by Bavarian State Ministry of the Environment and Public Health.

\section{LITERATURE CITED}

Barry RG (1981) Mountain weather and climate. Methuen, London

Cannone N, Diolaiuti G, Guglielmin M, Smiraglia C (2008) Accelerating climate change impacts on alpine glacier forefield ecosystems in the European Alps. Ecol Appl 18: $637-648$

Defila C, Clot B (2001) Phytophenological trends in different seasons, regions and altitudes in Switzerland. In: Walther GR, Burga CA, Edwards PJ (eds) 'Fingerprints' of climate change: adapted behaviour and shifting species ranges. Kluwer Academic/Plenum Press, New York

- Defila C, Clot B (2005) Phytophenological trends in the Swiss Alps, 1951-2002. Meteorol Z 14:191-196

Dittmar C, Elling W (2006) Phenological phases of common beech (Fagus sylvatica L.) and their dependence on region and altitude in southern Germany. Eur J For Res 125: 181-188

Haylock MR, Hofstra N, Klein Tank AMG, Klok EJ and others (2008) A European daily high-resolution gridded dataset of surface temperature and precipitation for 1950-2006. J Geophys Res 113:D20119, doi: 10.1029/2008JD010201

WHO (World Health Organisation) (2003) Phenology and human health: allergic disorders. Report of a WHO meeting, Rome, Italy, 16-17 January 2003

Körner C (2007) The use of 'altitude' in ecological research. Trends Ecol Evol 22:569-574

Larcher W (2006) Altitudinal variation in flowering time of lilac (Syringa vulgaris L.) in the Alps in relation to temperatures. Oesterr Akad Wiss Math-Natwiss Kl Sitzungsber Abt I 212:3-18

Menzel A (2002) Phenology: its importance to the global change community. Clim Change 54:379-385

Menzel A, Sparks TH, Estrella N, Koch E and others (2006) European phenological response to climate change matches the warming pattern. Glob Change Biol 12: 1969-1976

Michel FB, Cour P, Quet L, Marty JP (1976) Qualitative and quantitative comparison of pollen calendars for plain and mountain areas. Clin Exp Allergy 6:383-393

Rosenzweig C, Casassa G, Karoly DJ, Imeson A and others (2007) Assessment of observed changes and responses in natural and managed systems. In: Parry ML, Canziani OF, Palutikof JP, van der Linden PJ, Hanson CE (eds) Climate change 2007: impacts, adaptation and vulnerability. Contribution of Working Group II to the Fourth Assessment Report of the Intergovernmental Panel on Climate Change. Cambridge University Press, Cambridge, p 79-131

> Studer S, Appenzeller C, Defila C (2005) Inter-annual variability and decadal trends in Alpine spring phenology: a multivariate analysis approach. Clim Change 73:395-414

Walther GR, Post E, Convey P, Menzel A and others (2002) Ecological responses to recent climate change. Nature 416:389-395

Proofs received from author(s): August 21, 2009 